\title{
EFFECT OF GRADED SUPPLEMENTATION OF CALCIUM SALTS OF PALM FATTY ACIDS ON LACTATION PERFORMANCE OF NILI RAVI BUFFALOES
}

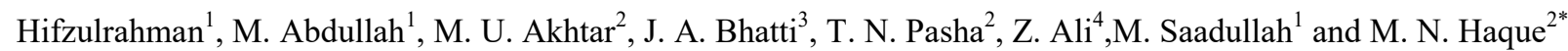 \\ ${ }^{1}$ Department of Livestock Production, University of Veterinary and Animal Sciences, Lahore; ${ }^{2}$ Department of Animal \\ Nutrition, University of Veterinary and Animal Sciences, Lahore; ${ }^{3}$ College of Veterinary and Animal Sciences, Jhang; \\ ${ }^{4}$ Applied Chemistry Research Center, Pakistan Council of Scientific and Industrial Research Laboratories Complex, Lahore \\ *Corresponding author's e-mail: muhammad.naveed@uvas.edu.pk
}

https://doi.org/10.36899/JAPS.2020.1.0004

Published online January 02, 2020

\begin{abstract}
The objective of this study was to investigate the effect of graded amount of calcium salts of palm fatty acids (Ca-PFA) supplementation on dry matter intake, milk yield, milk fat, and milk fatty acid profile in lactating buffalo. Twelve multiparous early-lactating buffaloes were arranged in a $4 \times 4$ Latin-square design with a period length of 21 day. The 4 treatments were basal diet with supplementation of $0,200,400$, and $600 \mathrm{~g}$ of Ca-PFA per day. The 3.5\% fat-corrected milk yield, milk fat content, and milk fat yield showed a quadratic function with a transient maximumat $400 \mathrm{~g} / \mathrm{d}$ of supplemental level. The concentration and yield of C16:0 and C18:0 increased linearly, whereas concentration of C16:1 and C18:2 passed a transient maximum and afterward decreased upon intake of Ca-PFA. The C16:0 yield tended to increase linearly, whereas C16:1 yield showed a quadratic function with increasing Ca-PFA intake. Cumulatively, increasing the Ca-PFA supplementation decreased the content and yield of de novo milk FA by $21.7 \%$ and increased preformed milk FA by approximately $10.0 \%$. In conclusion, under the current feeding scheme, the elevated Ca-PFA intake increased milk and milk fat yields and the responses were maximal at $400 \mathrm{~g} / \mathrm{dof}$ Ca-PFA supplemental level.
\end{abstract}

Key words: Palm fatty acid, milk yield, milk fatty acid, buffalo.

\section{INTRODUCTION}

The water buffalo (Bubalus bubalis) is ranked second among livestock because of its contribution to global milk supplies ( $15 \%$ of the total) total amounting to 120 billion liters produced annually (FAOSTAT, 2017). In Pakistan, 13.7 million milking buffaloes produced around 27.3 billion liters of milk with herd average of $5.45 \mathrm{~kg} /$ buffalo per day (FAOSTAT, 2017), far lower than the milk average of Holstein $(28.7 \mathrm{~kg} / \mathrm{d}$; FAOSTAT, 2017). Conversely, buffalo milk contains higher fat content (7.8 $\pm 2.3 \%$; Pegolo et al., 2017) compared with cow milk (3.84\%; USDA, 2017). Increased milk fat-toprotein ratio in buffalo milk indicates that the demand of energy for milk production in lactating buffalo might be higher compared to cow. Interestingly, the fatty acid (FA) composition of buffalo milk is similar to cow milk (Pegolo et al., 2017). This similar composition of FA in buffalo and cow milk offers an opportunity to investigate the advantages of fat feeding to increase milk yield and milk composition in buffalo.

Calcium salts of palm fatty acids (Ca-PFA)based products are the alternate sources of energy that has been shown to increase milk yield from 15 to $20 \%$ and milk fat yield from 8.36 to $10.5 \%$ in dairy cow (Batistel et al., 2017; de Souza et al., 2017). Likewise, a study conducted in lactating buffalo by feeding $300 \mathrm{~g} / \mathrm{d}$ of Ca-PFA observed an increase of $22 \%$ in milk yield
(Polidori et al., 1997). Recently, our research group investigated the effects of feeding Ca-PFA in lactating buffalo and observed an increased milk yield by $7.85 \%$ and milk fat yield by $14.3 \%$ (Hifzulrahman et al., 2019). Nevertheless, high levels of feeding Ca-FA could decrease the DMI (Schauf and Clark, 1992; Rabiee et al., 2012) and consequently the milk yield (Schauf and Clark, 1992). Previously, Ca-PFA was fed from 100 to $300 \mathrm{~g} / \mathrm{d}$ in lactating buffalo (Polidori et al., 1997; Ranjan et al., 2012) and from 100 to $1764 \mathrm{~g} / \mathrm{d}$ in dairy cow (Schauff and Clark, 1992; Piperova et al., 2004; Beaulieu and Palmquist, 1995). To our knowledge, no study has been conducted to investigate the optimal amount of Ca-PFA to supplement in the diets fed to lactating buffalo. Our hypothesis is that the positive impact on milk yield would decrease after passing the optimum supplementation of Ca-PFA. Therefore, the aim of this study was to determine the optimum level of supplementing the CaPFA in lactating buffalo by graded increase in its level from 0 to $600 \mathrm{~g} / \mathrm{d}$ in the diet and observing its effects on DMI, milk yield, milk fat, and milk FA profile.

\section{MATERIALS AND METHODS}

Animals: The experiment was conducted from November 2015 to January 2016 in a tie-stall barn located at University of Veterinary \& Animal Sciences, Ravi Campus $\left(31.02^{\circ} \mathrm{N}, 73.85^{\circ} \mathrm{E}\right.$, and $186 \mathrm{~m}$ altitude; 
Pattoki, Pakistan). Twelve lactating multiparous Nili Ravi buffaloes, with (mean \pm SD) $9.30 \pm 1.39 \mathrm{~kg} / \mathrm{d}$ of milk yield, $5.06 \pm 0.91 \%$ milk fat, $506 \pm 54 \mathrm{~kg}$ of BW, and 56 \pm 21 DIM were used. The buffaloes were kept individually in a naturally ventilated barn and had free access to automatic drinking bowls.

Treatments and Experimental Design: Dietary treatments were consisted of no supplemental fat and 3 supplemental levels of Ca-PFA (RumiFat Plus, EcolexSdn. Bhd. Selangor, Malaysia) added to the basal diet in a $4 \times 4$ Latin square design. The duration of each period was 21 day given one week of adaptation before each period. The amount of Ca-PFA was supplemented daily to target intakes of $0,200,400$, and $600 \mathrm{~g} / \mathrm{d}$ per buffalo. The diet was formulated using Cornell-PennMiner-Dairy 3.0.10 from Cornell University (Ithaca, NY), University of Pennsylvania (Philadelphia, PA), and Miner Institute (Chazy, NY), based on CNCPS 5.0.2 (Fox et al., 2003). The diet was formulated to support 9 $\mathrm{kg}$ of milk with $8 \%$ milk fat and $4 \%$ crude protein in milk. The ME balance and MP balance were supporting this production as per CNCPS model. Ingredient and chemical composition of the diet is presented in Table 1 and 2. The Ca-PFA supplement (RumiFat Plus) consisted of $1.2 \%$ myristic acid, $47 \%$ palmitic acid, $5.0 \%$ stearic acid, 38\% oleic acid, and $8.0 \%$ linoleic acid. The diets were offered in a fixed amount per buffalo and Ca-PFA supplement was top-dressed individually. Buffaloes were relatively similar in $\mathrm{BW}$; hence, they were offered a similar quantity of DM $(13.9 \mathrm{~kg} /$ buffalo per day on DM basis) assuming similar lactation persistency in the entire experiment. Separately prepared concentrate was mixed with silage and wheat straw before offering to each group. The buffaloes were fed once daily at $0900 \mathrm{~h}$.

Experimental Measures, Sampling, and Analyses: Feed intake was observed on daily basis. Three samples of each feedstuff were collected weekly in each period to evaluate the DM and for further laboratory analysis. Samples of each feedstuff in triplicate were collected weekly in each period and analyzed for chemical composition following AOAC international (2005). Buffaloes were milked twice daily at 0600 and $1800 \mathrm{~h}$. Milk production was recorded at each milking. Milk samples were taken on alternate days in first 2 weeks and continuously from day 15 to 21 of each period. Milk production from morning and evening milking were pooled daily and analyzed by Gerber method for milk fat content (IDF, 1981). An aliquot of milk from day 21 of each period was stored at $-20^{\circ} \mathrm{C}$ without preservative until analyzed for FA profile as described by Hifzulrahman et al. (2019). Samples from all the buffaloes were collected on $3^{\text {rd }}$ last day of each period in heparinized syringes and immediately centrifuged at $2,000 \times \mathrm{g}$ for $15 \mathrm{~min}$ at $4^{\circ} \mathrm{C}$. Plasma was separated, aliquoted, and stored at $-20^{\circ} \mathrm{C}$ to be assayed by enzymatic method as described by Hifzulrahman et al. (2019).

Calculations and Statistics: Data were analyzed using the GLIMMIX procedure of SAS University Edition (SAS Institute Inc., Cary, NC), with main effects of period and treatments, whereas buffaloes were designated as random effect in the model. Treatments were compared with linear and quadratic polynomial models to examine the response surface for the level of Ca-PFA. Standard errors of the mean are reported and treatment differences were considered significant if $\mathrm{P} \leq 0.05$ and as a trend for $0.05<\mathrm{P} \leq 0.10$.

\section{RESULTS}

Fatty Acids Intake: The FA intakes are presented in Table 3. The intake of C16:0 was increased by $553 \%$ with the supplemental level of $600 \mathrm{~g} / \mathrm{d}$ of Ca-PFA. However, the intake of $\mathrm{C} 16: 1$ was linearly decreased $(\mathrm{P}<0.01)$ with increasing Ca-PFA intake. Similarly, the total FA intake was linearly increased $(\mathrm{P} \leq 0.01)$ by $173 \%$ with $600 \mathrm{~g} / \mathrm{d}$ of Ca-PFA intake.

Feed Intake, Milk Production, and Milk Composition: Dry matter intake, milk production, and milk fat results are presented in Table 4. A trend for a quadratic decrease $(\mathrm{P}=0.08)$ was observed on DMI with increasing Ca-PFA intake. The Ca-PFA intake increased the milk yield quadratically $(\mathrm{P}=0.04)$. Milk fat concentration and yields of $3.5 \% \mathrm{FCM}$ and milk fat showed a quadratic increase $(\mathrm{P}<0.05)$ and were maximized with $400 \mathrm{~g} / \mathrm{d}$ of supplemental level.

Milk Fatty Acids Concentration: The concentrations of milk FA are presented in Table 5. Concentrations of C6:0-C14:1 were linearly decreased by increasing CaPFA supplementation $(\mathrm{P} \leq 0.01)$. Increasing the Ca-PFA intake showed a linear increase in the concentration of $\mathrm{C} 16: 0 \quad(\mathrm{P} \leq 0.01)$ and a quadratic increase in $\mathrm{C} 16: 1$ $(\mathrm{P} \leq 0.01)$. The $\mathrm{C} 18: 0$ increased linearly $(\mathrm{P} \leq 0.01)$ and $\mathrm{C} 18: 2$ quadratically $(\mathrm{P} \leq 0.01)$ with increasing Ca-PFA intake, whereas concentration of C18:1 was not affected by the treatments. The Ca-PFA supplementation decreased linearly the content of de novo milk FA by $21.7 \%$ ( $\mathrm{P} \leq 0.01)$, whereas increased the concentration of mixed milk FA and preformed milk FA by 7.63 and $10.6 \%$, respectively $(\mathrm{P} \leq 0.01)$. Increasing the Ca-PFA intake showed a quadratic effect in the concentration of SFA and PUFA $(\mathrm{P} \leq 0.01)$, whereas MUFA remained unaffected $(\mathrm{P}>0.10)$.

Milk Fatty Acids Yield: Milk FA yields are presented in Table 6. Increasing the Ca-PFA supplementation decreased the yield of C6:0, C8:0, C10:0, and C12:0 linearly $(\mathrm{P} \leq 0.01)$. The $\mathrm{C} 14: 0$ yield showed a decreasing tendency linearly $(\mathrm{P}=0.07)$, whereas $\mathrm{C} 14: 1$ yield 
decreased quadratically $(\mathrm{P} \leq 0.01)$. The $\mathrm{C} 16: 0$ yield tended to increase linearly $(\mathrm{P}=0.08)$, whereas $\mathrm{C} 16: 1$ yield increased quadratically $(\mathrm{P}=0.01)$ with increasing $\mathrm{Ca}$ PFAintake. The Ca-PFA intake increased the yield of C18:0 linearly $(\mathrm{P} \leq 0.01)$ and the yield of $\mathrm{C} 18: 2$ quadratically $(\mathrm{P}=0.01)$. The yield of the $\mathrm{C} 18: 1$ remained unaffected $(\mathrm{P}>0.10)$. The yield of de novo milk FA was decreased by $21.8 \%(\mathrm{P}<0.01)$. Preformed milk FA were linearly increased by $9.88 \%(\mathrm{P}=0.03)$ with increasing $\mathrm{Ca}-$ PFA intake.

Table 1. Ingredient composition of the basal diet.

\begin{tabular}{lc}
\hline Ingredient & \% of DM \\
\hline Corn silage & 21.7 \\
Wheat straw & 27.4 \\
Wheat bran & 12.8 \\
Canola meal & 6.50 \\
Ground corn & 15.9 \\
Sugarcane molasses & 5.27 \\
Soybean meal & 9.74 \\
Mineral premix & 0.72 \\
Total & 100 \\
\hline
\end{tabular}

Table 2. Nutrient composition of the treatment ${ }^{1}$ diets.

\begin{tabular}{lcccc}
\hline Item & \multicolumn{1}{c}{$\mathbf{0}$} & $\mathbf{2 0 0}$ & $\mathbf{4 0 0}$ & $\mathbf{6 0 0}$ \\
\cline { 1 - 2 } Ingredient, (\% of DM, unless noted) & & \\
DM, (\%) & 62.7 & 63.0 & 63.4 & 63.7 \\
Forage & 49.1 & 48.3 & 47.6 & 46.8 \\
CP & 12.0 & 11.8 & 11.7 & 11.5 \\
NDF & 45.1 & 44.4 & 43.7 & 43.0 \\
ADF & 27.1 & 26.7 & 26.3 & 25.8 \\
NFC & 34.4 & 33.9 & 33.5 & 32.9 \\
Ether extract total & 2.69 & 3.95 & 5.21 & 6.47 \\
Ash & 7.61 & 7.69 & 7.78 & 7.86 \\
Predicted nutritive values & & & & \\
RUP, (\% CP) & 32.2 & 32.1 & 32.1 & 32.0 \\
ME, (Mcal/kg) & 2.23 & 2.33 & 2.43 & 2.53 \\
NE, (Mcal/kg) & 1.44 & 1.50 & 1.57 & 1.63 \\
\hline
\end{tabular}

${ }^{1}$ Treaments consisted of the basal ration (0) plus calcium salts of palm fatty acid (RumiFat Plus, EcolexSdn. Bhd. Selangor, Malaysia) to target intakes of 200,400 , and $600 \mathrm{~g} / \mathrm{d}$.

Plasma Metabolites: Results of plasma metabolites are summarized in Table 7. Plasma urea nitrogen was affected quadratically by increasing Ca-PFA intake $(\mathrm{P}=0.01)$, whereas blood glucose and triglyceride concentrations were not different across the treatment levels $(\mathrm{P}>0.10)$.

Table 3. Fatty acid (FA) intake in different treatments ${ }^{1}$.

\begin{tabular}{|c|c|c|c|c|c|c|c|}
\hline \multirow[b]{2}{*}{ FA intake, (g/d) } & \multicolumn{4}{|c|}{ Treatment } & \multirow[b]{2}{*}{ SEM } & \multicolumn{2}{|c|}{ P-value } \\
\hline & $\mathbf{0}$ & 200 & 400 & 600 & & Linear & Quadratic \\
\hline $\mathrm{C} 12: 0$ & 0.47 & 0.79 & 1.11 & 1.42 & 0.005 & $<0.01$ & 0.58 \\
\hline $\mathrm{C} 14: 0$ & 2.51 & 5.07 & 7.69 & 10.2 & 0.04 & $<0.01$ & 0.39 \\
\hline $\mathrm{C} 16: 0$ & 41.2 & 117 & 194 & 269 & 0.9 & $<0.01$ & 0.63 \\
\hline C16:1 & 0.68 & 0.67 & 0.66 & 0.65 & 0.004 & $<0.01$ & 0.90 \\
\hline C18:0 & 5.73 & 12.3 & 19.0 & 25.5 & 0.09 & $<0.01$ & 0.53 \\
\hline C18:1 & 57.5 & 115 & 173 & 229 & 0.8 & $<0.01$ & 0.38 \\
\hline $\mathrm{C} 18: 2$ & 133 & 143 & 153 & 161 & 0.8 & $<0.01$ & 0.35 \\
\hline $\mathrm{C} 18: 3$ & 28.8 & 28.2 & 27.9 & 27.4 & 0.17 & $<0.01$ & 0.81 \\
\hline Other & 4.62 & 11.7 & 18.9 & 25.9 & 0.09 & $<0.01$ & 0.64 \\
\hline Total FA & 275 & 433 & 595 & 750 & 2.8 & $<0.01$ & 0.60 \\
\hline
\end{tabular}

${ }^{1}$ Treaments consisted of the basal ration (0) plus calcium salts of palm fatty acid (RumiFat Plus, EcolexSdn. Bhd. Selangor, Malaysia) to target intakes of 200,400 , and $600 \mathrm{~g} / \mathrm{d}$.

Table 4. Response of DMI, milk yield, and milk fat in different treatments ${ }^{1}$.

\begin{tabular}{lccccccc}
\hline & \multicolumn{4}{c}{ Treatment } & & \multicolumn{2}{c}{$\boldsymbol{P}$-value } \\
\cline { 2 - 4 } Item & $\mathbf{0}$ & $\mathbf{2 0 0}$ & $\mathbf{4 0 0}$ & $\mathbf{6 0 0}$ & SEM & Linear & Quadratic \\
\hline DMI, (kg/d) & 12.5 & 12.6 & 12.5 & 12.4 & 0.07 & 0.17 & 0.08 \\
Milk yield, (kg/d) & 8.67 & 9.05 & 9.39 & 8.84 & 0.357 & 0.39 & 0.04 \\
$3.5 \%$ FCM,(kg/d) & 11.1 & 12.3 & 13.0 & 11.8 & 0.51 & 0.09 & $<0.01$ \\
Milk fat, $(\%)$ & 5.55 & 5.72 & 5.99 & 5.73 & 0.115 & 0.07 & 0.04 \\
Milk fat yield,(g/d) & 465 & 514 & 553 & 503 & 24.0 & 0.05 & 0.01 \\
\hline
\end{tabular}

${ }^{\mathrm{I}}$ Treaments consisted of the basal ration (0) plus calcium salts of palm fatty acid (RumiFat Plus, EcolexSdn. Bhd. Selangor, Malaysia) to target intakes of 200,400 , and $600 \mathrm{~g} / \mathrm{d}$. 
Table 5. Milk fatty acid profile.

\begin{tabular}{|c|c|c|c|c|c|c|c|}
\hline \multirow[b]{2}{*}{ Item } & \multicolumn{4}{|c|}{ Treatment $^{1}$} & \multirow[b]{2}{*}{ SEM } & \multicolumn{2}{|c|}{ P-value } \\
\hline & $\mathbf{0}$ & 200 & 400 & 600 & & Linear & Quadratic \\
\hline \multicolumn{8}{|l|}{ Fatty acid, (g/100 g) } \\
\hline C6:0 & 1.85 & 1.65 & 1.13 & 0.93 & 0.115 & $<0.01$ & 1.00 \\
\hline $\mathrm{C} 8: 0$ & 1.00 & 0.83 & 0.68 & 0.60 & 0.033 & $<0.01$ & 0.12 \\
\hline C10:0 & 1.95 & 1.55 & 1.60 & 1.35 & 0.064 & $<0.01$ & 0.10 \\
\hline $\mathrm{C} 12: 0$ & 2.38 & 2.03 & 1.80 & 1.70 & 0.057 & $<0.01$ & 0.04 \\
\hline $\mathrm{C} 14: 0$ & 10.5 & 9.98 & 9.25 & 9.30 & 0.162 & $<0.01$ & 0.07 \\
\hline $\mathrm{C} 14: 1$ & 1.70 & 1.98 & 1.88 & 1.33 & 0.097 & $<0.01$ & $<0.01$ \\
\hline $\mathrm{C} 16: 0$ & 35.4 & 37.2 & 36.7 & 38.7 & 0.41 & $<0.01$ & 0.87 \\
\hline C16:1 & 3.88 & 4.35 & 4.13 & 3.60 & 0.166 & 0.14 & $<0.01$ \\
\hline C18:0 & 13.9 & 12.0 & 14.2 & 16.0 & 0.24 & $<0.01$ & $<0.01$ \\
\hline C18:1 & 18.9 & 18.2 & 19.1 & 19.3 & 0.61 & 0.42 & 0.48 \\
\hline C18:2 & 2.27 & 3.82 & 2.63 & 3.22 & 0.148 & 0.01 & $<0.01$ \\
\hline \multicolumn{8}{|l|}{ Summation by source } \\
\hline$\sum<\mathrm{C} 16$ & 19.4 & 18.0 & 16.3 & 15.2 & 0.29 & $<0.01$ & 0.64 \\
\hline$\sum \mathrm{C} 16: 0+\mathrm{C} 16: 1$ & 39.3 & 41.6 & 40.9 & 42.3 & 0.47 & $<0.01$ & 0.30 \\
\hline$\sum>\mathrm{C} 16$ & 35.0 & 34.0 & 37.5 & 38.7 & 0.75 & $<0.01$ & 0.13 \\
\hline \multicolumn{8}{|c|}{ Summation by saturation } \\
\hline$\sum$ Saturated & 67.0 & 65.3 & 65.4 & 68.6 & 0.54 & 0.05 & $<0.01$ \\
\hline$\sum$ Monounsaturated & 24.5 & 24.6 & 25.1 & 24.3 & 0.47 & 0.98 & 0.32 \\
\hline$\sum$ Polyunsaturated & 2.27 & 3.82 & 2.63 & 3.22 & 0.148 & 0.01 & $<0.01$ \\
\hline
\end{tabular}

Table 6. Milk fatty acid yield.

\begin{tabular}{|c|c|c|c|c|c|c|c|}
\hline \multirow[b]{2}{*}{ Fatty acid, (g/d) } & \multicolumn{4}{|c|}{ Treatment $^{1}$} & \multirow[b]{2}{*}{ SEM } & \multicolumn{2}{|c|}{ P-value } \\
\hline & $\mathbf{0}$ & 200 & 400 & 600 & & Linear & Quadratic \\
\hline C6:0 & 9.17 & 8.40 & 5.94 & 4.53 & 0.715 & $<0.01$ & 0.66 \\
\hline C8:0 & 4.94 & 4.21 & 3.56 & 2.94 & 0.269 & $<0.01$ & 0.82 \\
\hline C10:0 & 9.62 & 7.90 & 8.51 & 6.65 & 0.548 & $<0.01$ & 0.86 \\
\hline C12:0 & 11.7 & 10.3 & 9.55 & 8.35 & 0.565 & $<0.01$ & 0.90 \\
\hline $\mathrm{C} 14: 0$ & 51.8 & 50.7 & 49.2 & 45.8 & 2.61 & 0.07 & 0.62 \\
\hline C14:1 & 8.38 & 10.0 & 10.0 & 6.54 & 0.685 & 0.04 & $<0.01$ \\
\hline $\mathrm{C} 16: 0$ & 174 & 189 & 196 & 190 & 8.8 & 0.08 & 0.16 \\
\hline C16:1 & 19.0 & 22.2 & 21.9 & 17.8 & 1.23 & 0.46 & $<0.01$ \\
\hline C18:0 & 68.2 & 61.0 & 75.5 & 78.6 & 3.29 & $<0.01$ & 0.04 \\
\hline C18:1 & 92.6 & 92.6 & 102 & 95.3 & 5.42 & 0.39 & 0.46 \\
\hline $\mathrm{C} 18: 2$ & 11.2 & 19.4 & 14.2 & 15.5 & 1.34 & 0.13 & 0.01 \\
\hline \multicolumn{8}{|l|}{ Summation by source } \\
\hline$\sum<\mathrm{C} 16$ & 95.6 & 91.5 & 86.8 & 74.8 & 4.70 & $<0.01$ & 0.34 \\
\hline$\sum \mathrm{C} 16: 0+\mathrm{C} 16: 1$ & 193 & 211 & 218 & 208 & 9.7 & 0.14 & 0.09 \\
\hline $\bar{\sum}>\mathrm{C} 16$ & 172 & 173 & 199 & 189 & 10.7 & 0.03 & 0.51 \\
\hline \multicolumn{8}{|c|}{ Summation by saturation } \\
\hline$\sum$ Saturated & 329 & 331 & 348 & 337 & 15.8 & 0.46 & 0.61 \\
\hline$\sum$ Monounsaturated & 120 & 125 & 134 & 120 & 6.3 & 0.72 & 0.06 \\
\hline$\sum$ Polyunsaturated & 11.2 & 19.4 & 14.2 & 15.5 & 1.34 & 0.13 & 0.01 \\
\hline
\end{tabular}


Table 7. Plasma metabolites.

\begin{tabular}{|c|c|c|c|c|c|c|c|}
\hline \multirow[b]{2}{*}{ Item, (mg/dL) } & \multicolumn{4}{|c|}{ Treatment } & \multirow[b]{2}{*}{ SEM } & \multicolumn{2}{|c|}{ P-value } \\
\hline & $\mathbf{0}$ & 200 & 400 & 600 & & Linear & Quadratic \\
\hline Plasma urea nitrogen & 22.7 & 21.9 & 20.3 & 23.5 & 0.77 & 0.82 & 0.01 \\
\hline Glucose & 92.2 & 89.9 & 91.6 & 95.0 & 2.72 & 0.41 & 0.31 \\
\hline Triglyceride & 148 & 158 & 163 & 156 & 6.3 & 0.28 & 0.17 \\
\hline
\end{tabular}

${ }^{1}$ Treaments consisted of the basal ration (0) plus calcium salts of palm fatty acid (RumiFat Plus, EcolexSdn. Bhd. Selangor, Malaysia) to target intakes of 200,400 , and $600 \mathrm{~g} / \mathrm{d}$.

\section{DISCUSSION}

Feeding of Ca-PFA in dairy cows has been shown to increase the milk yield and milk fat yield through increased energy supplies (Polidori et al., 1997; de Souza et al., 2017; Batistel et al., 2017). Moreover, these positive effects can be achieved without the risk of acidosis associated with feeding high amount of fermentable carbohydrates (Jenkins and McGuire, 2006). However, Ca-FAs need to be used with caution, because, at higher levels of supplementation, it might negatively affect the ruminal fermentation and decrease the performance of dairy cow (Schauf and Clark, 1992; Beaulieu and Palmquist, 1995). Ca-PFA supplements are well-investigated and commonly used fat supplements of dairy cow ration. Yet, no study investigated the effects of graded supplementation of Ca-PFA in lactating buffaloto the best of our knowledge. Therefore, our objective was to determine the optimum feeding level of Ca-PFA on milk yield and milk FA profile in lactating buffaloes.

Slight Decrease in the DMI at High Ca-PFA Supplementation: In literature, variable responses on DMI were reported depending upon the amount of $\mathrm{Ca}$ PFA supplementation. In the study by Schauf and Clark (1992), the DMI started decreasing when Ca-PFA intake was $735 \mathrm{~g} / \mathrm{d}$ or $3 \%$ of the DMI. Contrary to this, in recent studies (de Souza et al., 2017; Batistel et al., 2017), supplementation of Ca-PFA showed no effect on DMI at feeding rate of $400 \mathrm{~g} / \mathrm{d}(2-2.4 \%$ of the DMI). However, in the present study, the supplementation of Ca-PFA was increased from 0 to $4.8 \%$ of the DM and we observed a quadratic trend toward decrease in the DMI by $0.81 \%$ at the feeding level of $600 \mathrm{~g} / \mathrm{d}$. It is possible that higher supply of unsaturated FA in the rumen exceeds the microbial capacity to convert them into the saturated FA leading to impeded ruminal fermentation (NRC, 2001; Rabiee et al., 2012). This could be further supported by the fact that the proportions of milk FA in our experiment were altered indicating a change in the ruminal fermentation (Beaulieu and Palmquist, 1995). It is also theorized that the unsaturated FA reaching the small intestine stimulate release of cholecystokinin and glucose-dependent insulinotropic peptide -1 , both of which regulate satiety and DMI in the cow (see Choi and
Palmquist, 1996; Bradford et al., 2008; Relling and Reynolds, 2007).

3.5\% FCM Yield Increased with Ca-PFA Supplementation: Present study showed a quadratic response in production parameters with increasing levels of the Ca-PFA. Previous studies reported increased milk production with Ca-PFA supplementation in lactating buffaloes (Polidori et al., 1997) and cows (Schauf and Clark, 1992; de Souza et al., 2017; Batistel et al., 2017). Polidori et al. (1997) observed $22 \%$ increase in milk production with the supplementation of $300 \mathrm{~g} / \mathrm{d}$ of CaPFA, whereas it was $8.3 \%$ at supplementation of $400 \mathrm{~g} / \mathrm{d}$ in the current study. The high CP level of the diet $(17.2 \%$ of DM) used in the study by Polidori et al. (1997) compared with the present study $(11.7 \%$ of the DM) could be a possible explanation to this difference in milk yield as the interaction between concentration of protein and fat level has been reported in literature (Petit et al., 2005; Santillo et al., 2016). A logical explanation to the increased milk yield in our study is the increased supply of energy at high Ca-PFAsupplementation. Besides, the increase in milk yield could also be explained using glucose sparing mechanism proposed in the literature (Palmquist and Jenkins, 1980). Similarly, in present study this mechanism is further supported by lower yields of de novo FA and higher yields of preformed FA. The decrease in de novo FA synthesis spare extra glucose for lactose synthesis (Palmquist and Jenkins, 1980). On the other hand, higher use of preformed FA may also spare glucose for lactose synthesis and consequently the increased milk production (Cant et al., 1993a, b).

Increased Milk Fat Yield with Ca-PFA Supplementation: In our study, the milk fat yield increased by $18.9 \%$ with $400 \mathrm{~g} / \mathrm{d}$ Ca-PFA intake. These results were in agreement with the increase of milk fat yield by 10.5 and $6.56 \%$ reported by de Souza et al. (2017) and Batistel et al. (2017), respectively, by feeding $400 \mathrm{~g} / \mathrm{d}$ Ca-PFA supplementation in dairy cow. The increase in milk fat yield observed in our study could be explained by the increased concentration and yield of preformed FA (18-C FA), which are preferred for milk fat synthesis during esterification process (Hansen and Knudsen, 1987). Besides, the higher milk C16:0 may further justify the increased milk fat content and yield in our study. It is possible that the dietary C16:0 stimulated 
de novo synthesis of milk C16:0 (Rico et al., 2014), thereby, incorporating it directly into triacylglycerol by dispersed mammary gland epithelial cells (Hansen and Knudsen, 1987). Moreover, C16:0 are preferably incorporated into milk fat by the mammary gland, compared to other FA (Loften et al., 2014). This increase of milk C16:0 with increasing dietary intake of C16:0 is also reported by others (Batistel et al., 2017; de Souza et al., 2017; Schauf and Clark, 1992).

Production Responses Decreased by $600 \mathrm{~g} / \mathrm{d}$ of CaPFA Supplementation: In our study, the responses of $3.5 \%$ FCM, milk fat content, and yield were maximal with $400 \mathrm{~g} / \mathrm{d}$ of Ca-PFA and then decreased at $600 \mathrm{~g} / \mathrm{d}$. The decrease in milk yield at $600 \mathrm{~g} / \mathrm{d}$ dose could be a result of over-supplementation of Ca-PFA in our study. The Ca-PFA and prilled fats have been reported to remain inert in the rumen provided they are supplemented below $3.5 \%$ or even $2-3 \%$ of DM in dairy cows (Grummer, 1988; Harvatine and Allen, 2006). In our study, the feeding of Ca-PFA was $3.8 \%$ of the DM at the dose of $600 \mathrm{~g} / \mathrm{d}$, consequently may not be rumen-inert to the same extent. Additionally, the protection of fats using calcium soap from ruminal biohydrogenation is also incomplete because unsaturated FA become available in rumen due to dissociation of the calcium ion $(\mathrm{Wu}$ et al., 1991), which lead to increased concentration of trans FA (Giesy et al., 2002; Chouinard et al., 1997) and increased formation of biohydrogenation intermediates that negatively affect ruminal bacterial populations and biohydrogenation pathways (Maia et al., 2007). This explanation is further supported by recent biohydrogenation theory, which suggests that under particular dietary conditions, intermediate products resulting from transformed ruminal biohydrogenation act on the mammary gland, which inhibits milk fat synthesis and affect milk FA profile (Bauman et al., 2011).

Milk Fatty Acids Proportion was Altered with CaPFA Supplementation: We found a decrease in de novo FA yield $(21.7 \%)$ and increase in preformed FA yield $(\sim 10.0 \%)$ with increasing Ca-PFA supplementation from 0 to $600 \mathrm{~g} / \mathrm{d}$, which is in agreement with the literature (Schauf and Clark, 1992; de Souza et al., 2017). Counter relation between these two groups of FA (de novo versus preformed) has been observed previously (Glasser et al., 2008). For example, de Souza et al. (2017) reported a decrease of $7.88 \%$ and increase of $13.0 \%$ in de novo and preformed milk FA, respectively, by feeding $400 \mathrm{~g} / \mathrm{d}$ of Ca-PFA compared to control. In that context, the reduction in de novo milk FA synthesis might be due to greater dissociation of Ca-PFA resulting in increased quantity of some trans FA production as an intermediate of ruminal biohydrogenation, which inhibit milk FA synthesis (Bauman et al., 2011; Bauman and Griinari, 2001).
Conclusions: In the current study, increasing the dietary intake of Ca-PFA $(0,200,400$, and $600 \mathrm{~g} / \mathrm{d})$ increased milk yield, milk fat yield, and altered milk FA profile in lactating Nili Ravi buffalo. Increased energy supplies primarily explain the increase in 3.5\% FCM yield, whereas the decreased yield of de novo FA in milk and decrease in the transfer of $\mathrm{C} 16: 0$ and 18-C FA from feed to milk indicate the use of these FA as metabolic fuel rather than export as milk triglycerides; hence, sparing glucose for lactose synthesis and increased milk yield. However, the increase in preformed FA yield and increasing trend of $\mathrm{C} 16: 0$ yield jointly explained the increase in milk fat yield. In the current feeding scheme, Ca-PFA at the rate of $400 \mathrm{~g} / \mathrm{d}$ is the optimum to produce positive productive response in lactating dairy buffaloes.

Acknowledgments: We acknowledge the support of dairy farm staff of UVAS Lahore, for their assistance in this research work. The authors thank the laboratory staff of UVAS, Lahore,for providing support in proximate analysis and Muhammad Imran, Department of Biochemistry for analysis of plasma. We also thank the staff of Pakistan Council of Scientific and Industrial Research Laboratories Complex, Lahore, for their help in analysis of milk samples for individual FA through gas chromatography. We acknowledge the support of Mehta brothers Pvt. Ltd. (Lahore) for providing the fat source used in this research at discounted price.

\section{REFERENCES}

AOAC(2005). Association of official analytical chemist official methods of analysis. Association of official analytical chemists 18th Ed. Gaithersburg USA, AOAC Press: 1250-1255.

Batistel, F., J. de Souza, and F.A.P. Santos (2017). Corn grain-processing method interacts with calcium salts of palm fatty acids supplementation on milk production and energy balance of earlylactation cows grazing tropical pasture. J. Dairy Sci. 100(7):5343-5357.

Bauman, D. and J. Griinari(2001). Regulation and nutritional manipulation of milk fat: low-fat milk syndrome. Livest. Prod. Sci. 70(1): 15-29.

Bauman, D.E., K.J. Harvatine, and A.L. Lock (2011). Nutrigenomics, rumen-derived bioactive fatty acids, and the regulation of milk fat synthesis. Annu. Rev. Nutr. 31:299-319.

Beaulieu, A. and D. Palmquist (1995). Differential effects of high fat diets on fatty acid composition in milk of Jersey and Holstein cows. J. Dairy Sci. 78(6):1336-1344.

Bradford, B., K. Harvatine, and M. Allen (2008). Dietary unsaturated fatty acids increase plasma glucagon-like peptide-1 and cholecystokinin and 
may decrease premeal ghrelin in lactating dairy cows. J. Dairy Sci. 91(4):1443-1450.

Cant, J.P., E.J. DePeters, and R.L. Baldwin (1993a). Mammary amino acid utilization in dairy cows fed fat and its relationship to milk protein depression. J. Dairy Sci. 76:762-774.

Cant, J.P., E.J. DePeters, and R.L. Baldwin (1993b). Mammary uptake of energy metabolites in dairy cows fed fat and its relationship to milk protein depression. J. Dairy Sci. 76:2254-2265.

Choi, B.R. and D.L. Palmquist (1996). High fat diets increase plasma cholecystokinin and pancreatic polypeptide, and decrease plasma insulin and feed intake in lactating cows. The J. Nutr. 126(11):2913-2919.

Chouinard, P., V. Girard, and G. Brisson(1997). Performance and profiles of milk fatty acids of cows fed full fat, heat-treated soybeans using various processing methods. J. Dairy Sci. 80(2):334-342.

de Souza, J., F. Batistel, and F.A.P. Santos (2017). Effect of sources of calcium salts of fatty acids on production, nutrient digestibility, energy balance, and carryover effects of early lactation grazing dairy cows. J. Dairy Sci. 100(2):10721085.

FAOSTAT (2017). Statistical database. Food and Agriculture Organization of the United Nations, Rome, Italy. Accessed July. 20, 2018. http://faostat3.fao.org.

Fox, D.G., T.P. Tylutki, L.O. Tedeschi, M.E. Van Amburgh, L.E. Chase, A.N. Pell, T.R. Overton, and J.B. Russell (2003). The Net Carbohydrate and Protein System for Evaluating Herd Nutrition and Nutrient Excretion: Model Documentation. Mimeo No. 213, Animal Science Department. Cornell University, Ithaca, NY.

Giesy, J., M. McGuire, B. Shafii, and T. Hanson (2002). Effect of dose of calcium salts of conjugated linoleic acid (CLA) on percentage and fatty acid content of milk fat in midlactation Holstein cows. J. Dairy Sci. 85(8):2023-2029.

Glasser, F., A. Ferlay, M. Doreau, P. Schmidely, D. Sauvant, and Y. Chilliard (2008). Long-chain fatty acid metabolism in dairy cows: A metaanalysis of milk fatty acid yield in relation to duodenal flows and de novo synthesis. J. Dairy Sci. 91(7):2771-2785.

Grummer, R.R. (1988). Influence of prilled fat and calcium salt of palm oil fatty acids on ruminal fermentation and nutrient digestibility. J. Dairy Sci. 71:117-123.

Hansen, H.O. and J. Knudsen (1987). Effect of exogenous long-chain fatty acids on individual fatty acid synthesis by dispersed ruminant mammary gland cells. J. Dairy Sci. 70(7):13501354.

Harvatine, K. and M. Allen (2006). Effects of fatty acid supplements on feed intake, and feeding and chewing behavior of lactating dairy cows. J. Dairy Sci. 89(3):1104-1112.

Hifzulrahman, M. Abdullah, M.U. Akhtar, T.N. Pasha, J.A. Bhatti, Z. Ali, M. Saadullah, and M.N. Haque (2019). Comparison of oil and fat supplementation on lactation performance of Nili Ravi buffaloes. J. Dairy Sci. 102:30003009.

IDF (1981). International Dairy Federation. Milk Determination of fat content (Gerber method). (International standard ISO-IDF 2446:2008). Brussels, Belgium.

Jenkins, T.C. and M.A. McGuire (2006). Major advances in nutrition: impact on milk composition. J. Dairy Sci. 89(4):1302-1310.

Loften, J., J. Linn, J. Drackley, T. Jenkins, C. Soderholm, and A. Kertz (2014). Invited review: Palmitic and stearic acid metabolism in lactating dairy cows. J. Dairy Sci. 97(8):4661-4674.

Maia, M.R., L.C. Chaudhary, L. Figueres, and R.J. Wallace (2007). Metabolism of polyunsaturated fatty acids and their toxicity to the microflora of the rumen. Antonie Van Leeuwenhoek. 91(4):303-314

NRC (2001). Nutrient requirements of dairy cattle. 7th rev. ed. Natl Acad Sci. Washigton, DC.

Palmquist, D.and T. Jenkins (1980). Fat in lactation rations: Review. J. Dairy Sci. 63(1):1-14.

Pegolo, S., G. Stocco, M. Mele, S. Schiavon, G. Bittante, and A. Cecchinato(2017). Factors affecting variations in the detailed fatty acid profile of Mediterranean buffalo milk determined by 2 dimensional gas chromatography. J. Dairy Sci. 100(4):2564-2576.

Petit, H.V., M.F. Palin, and L. Doepel (2010). Hepatic lipid metabolism in transition dairy cows fed flaxseed. J. Dairy Sci. 90(10):4780-4792.

Piperova, L.S., U. Moallem, B.B. Teter, J. Sampugna, M.P. Yurawecz, K.M. Morehouse, and R.A. Erdman (2004). Changes in milk fat in response to dietary supplementation with calcium salts of trans-18:1 or conjugated linoleic fatty acids in lactating dairy cows. J. Dairy Sci. 87(11), 38363844.

Polidori, F., C.S. Rossi, E. Senatore, G. Savoini, and V. Dell'Orto (1997). Effect of recombinant bovine somatotropin and calcium salts of long-chain fatty acids on milk from Italian buffalo. J. Dairy Sci. 80(9):2137-2142.

Ranjan, A., B. Sahoo, V.K. Singh, S. Srivastava, S.P. Singh, and A.K. Pattanaik (2012). Effect of bypass fat supplementation on productive 
performance and blood biochemical profile in lactating Murrah (Bubalus bubalis) buffaloes. Trop. Anim. Health Prod. 44(7): 1615-1621.

Rabiee, A., K. Breinhild, W. Scott, H. Golder, E. Block, and I. Lean. (2012). Effect of fat additions to diets of dairy cattle on milk production and components: A meta-analysis and metaregression. J. Dairy Sci. 95(6):3225-3247.

Relling, A. andC. Reynolds (2007). Feeding rumen-inert fats differing in their degree of saturation decreases intake and increases plasma concentrations of gut peptides in lactating dairy cows. J. Dairy Sci. 90(3):1506-1515.

Rico, J.E., M.S. Allen, and A.L. Lock (2014). Compared with stearic acid, palmitic acid increased the yield of milk fat and improved feed efficiency across production level of cows. J. Dairy Sci. 97:1057-1066.

Santillo, A., M. Caroprese, R. Marino, A. Sevi, and M. Albenzio (2016). Quality of buffalo milk as affected by dietary protein level and flaxseed supplementation. J. Dairy Sci. 99(10):77257732 .

SAS University Edition (2018). SAS Institute Inc., Cary, North Carolina, USA. Available from: https://www.sas.com/en_us/software/universityedition.html.

Schauff, D.J. and J.H. Clark (1992). Effects of feeding diets containing calcium salts of long-chain fatty acids to lactating dairy cows. J. Dairy Sci. 75(11), 2990-3002.

USDA-NASS (2017). National Agricultural Statistics Service. Livestock and Animals: Dairy. Accessed Mar. 17, 2019. Available from: https://www.nass.usda.gov/ Statistics_by_Subject/index.php?sector=ANIM ALS\%20\&\%20PRODUCTS.

Wu, Z., O. Ohajuruka, and D. Palmquist (1991). Ruminal synthesis, biohydrogenation, and digestibility of fatty acids by dairy cows. J. Dairy Sci. 74(9):3025-3034 